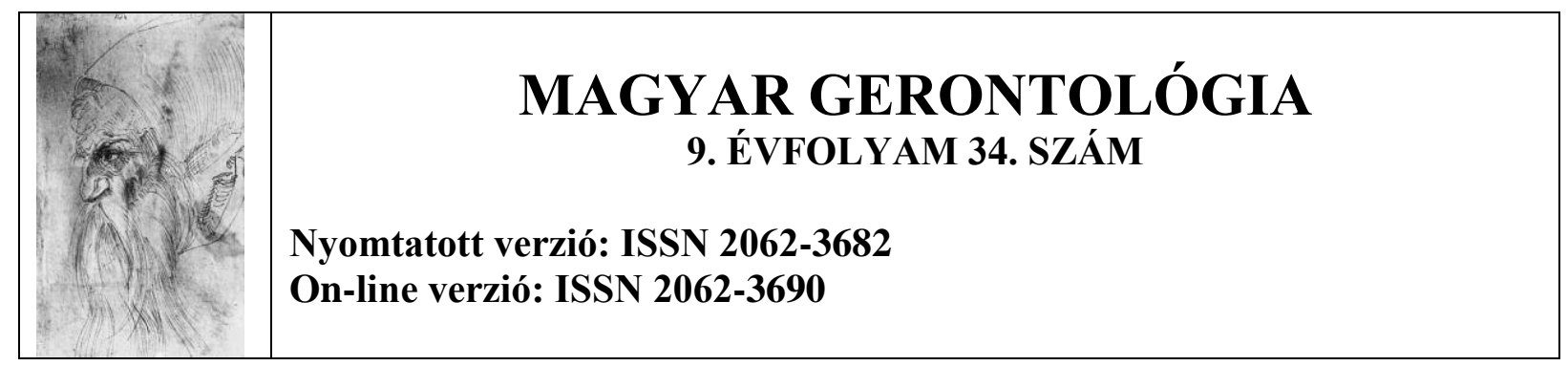

\title{
Összefoglaló
}

\section{AGE Platform Europe Policy Statement. Carer's leave and reconciling work and family life for older workers}

\author{
Szerző: AGE Platform Europe 2016. február \\ Az eredeti állásfoglalás forrása: \\ https://age-platform.eu/images/.../Carers_leave_and_reconciling_work
}

Az AGE Platform Europe egy nemzetközi n szervezet, mely az Európai Unió döntéshozatali mechanizmusaiban az idősek érdekeit igyekszik képviselni. A Gerontológiai Tudományos és Koordinációs Központ - mely a Debreceni Egyetem Egészségügyi Kar Gerontológiai Tanszékén müködik 2011 óta a szervezet teljes jogú tagja.

A nyilatkozat a gondozás és a munka összeegyeztetésének nehézségére, valamint a gondozók támogatásának szükségességére hívja fel a tagállamok figyelmét

A szervezet részt vesz az Európai Tanács 2016. évi konzultációjában, és mint tag üdvözli a Tanács kezdeményezését a munka és az élet összeegyeztetése témájában. Fontosnak tartja, hogy e témán belül külön szó essen a gondozási támogatások lehetőségeiről, amely lehetőséget nyújtanak a munka és a gondozás világainak összeegyeztetésére a családtagok számára, így az idősebb munkavállalók számára is.

Az AGE elfogadja, hogy a szociális innováció témája szintén fontos terület. A tagállamoknak komoly változások elé kell nézniük az informális gondozást végzők tekintetében. Fontos feladattá válik a gondozók munkaerő-piaci kompetenciáinak megőrzése a sokszor nem adekvát gondozási rendszerek mellett. E szolgáltatások egyre növekvő terhet rónak a függő helyzetben lévő és gondozásra szoruló idősek családtagjaira. Ezek a hatások különösen a 45-64 éves nők esetében érvényesülnek, akik a gondozás érdekében elhagyják a munkaerő-piacot azért, hogy a fiatalabb munkavállalókat tehermentesítsék a családban. 
Az AGE válasza erre az, hogy felhívja a figyelmet a gondozási támogatások biztosításának szükségességére. A támogatásokat úgy kell felfogni, mint befektetést a gondozási rendszerekbe az informális gondozók és gondozás biztosítása, vagy a formális gondozás érdekében, és biztosítja a munkavállalók rugalmasabb alkalmazkodását a munkaerő-piacon. Végül az AGE felhívja a figyelmet a nagyszülőkre, akik komoly szerepet töltenek be felnőtt gyermekeik támogatásában, a gondozásban és a képzésben.

\section{Háttér}

2015 nyarán az anyasági támogatások (gyes, stb.) kérdésköre került a fókuszba, amely egy 2008 óta zajló folyamat eredménye volt. Ebben a Tanács a munka és a gyermekgondozás összefüggéseit helyezte a középpontba. A Tanács 2015 decemberétől a munka és a családi élet összeegyeztetéséről indított vitát.

\section{Ki gondoz?}

Európában a 18 - 64 év közötti férfiak 12\%-a és a nők 16\%-a gondozza valamely családtagját legalább egy héten egy alkalommal. Az idősebb munkavállalók között (55-64) a férfiak 18\%a, és a nők $22 \%$-a végez gondozást. A többségnek van munkaviszonya, bár az informális gondozók felének, a részmunkaidőben foglalkoztatottak 30\%-ának nincsen.

A foglalkoztatási ráta különösen az idősebb (55-65) női munkavállalók körében drámaian alacsony $(45,2 \%)$ az EU28 tagállamaiban. Gyakori, hogy a gondozók nem merik elhagyni munkájukat a gondozói feladataikért, vagy attól félnek, hogy elveszítik munkájukat, vagy megtörik karrierjük, ha a gondozást választják. Negatív hatásokat eredményez a gondozás vállalása a későbbi nyugdíjjogosultságra, illetve a nyugdíj mértékére, valamint a szociális támogatásokra való jogosultság tekintetében is, mivel ezek sokkal alacsonyabbak a gondozást végzők esetében. A legtöbb EU tagállamban a formális gondozási szolgáltatások nem megfizethetőek, vagy nem elérhetőek bizonyos csoportok számára, akik gondozást igényelnek. Különösen igaz ez a gazdasági válság óta (2008), mivel sok országban ez a gondozási szolgáltatások szigorításához vezetett. A legtöbb országban csak a legsúlyosabb gondozási igényeket képesek kielégíteni és nem képesek figyelmet fordítani az olyan gondozási szükségletekre, mint az emocionális támogatás, vagy a napi tevékenységekben való segítés, így ezek a családi gondozók feladataiként jelennek meg. Ahogyan az államok nem képesek teljes körű formális szolgáltatásokat biztosítani, úgy az informális gondozók megmaradnak a gondozás értéktelen erőforrásaként, és emellett ők biztosítják az egészségkárosodott emberek befogadását, inklúzióját a társadalmakban. 


\section{Mi lehet a gondozási támogatások jogi támogatásának haszna?}

A gondozási támogatások jogi támogatása tiszta, pozitív hatást gyakorol mindazon egyének számára, akik gondozást nyújtanak, továbbá mindazoknak, akik ezt a gondozást igénybe veszik, csakúgy, mint a társadalom számára: a dolgozó informális gondozóknak nem kell elhagyniuk munkahelyeiket és a demográfiai öregedés gondozási költségei fenntarthatóbbakká válnak. Mindezek mellett a gondozási támogatások jogi támogatása nem jelenti azt, hogy a formális gondozás támogatásába és fejlesztésébe nem szükséges invesztálni, és azt sem, hogy a felelősség egységesen az idősebb munkavállalóké ettől kezdve. Érthetőbben fogalmazva, a gondozás egy koherens és összetett közpolitika része kell, hogy legyen.

A gondozási támogatás jó:

- A gondozottnak, mert folyamatos kapcsolatban lehet a családjával és saját közösségében, valamint környezetében élhet, megőrizheti aktivitását és egészségét

- $\quad$ Az informális gondozónak, mert megőrizheti munkáját és jövedelmét, védelmet élvez a jövedelem-kiesés és a betegség esetére, folytathatja a nyugdíjjogosultság elérését a folyamatos járulékfizetési jogviszony segítségével, megőrzi egyéb szociális jogait, beleértve a munkanélküli ellátásokhoz való jogát, és ideális esetben támogató szolgáltatásokat vehet igénybe, amelyek képzik, önsegítő csoportokat biztosítanak számukra, és helyettesítő szolgáltatásokat biztosítanak a kiégés megelőzésére.

\section{Gondozási támogatás - miről is beszélünk?}

A megfelelő támogatáshoz az alábbiak szükségesek:

Biztosítson lehetőséget az informális gondozás és a munka összeegyeztetésére: ahogyan a gyermeknevelési támogatás, úgy a gondozási támogatás is akkor tölti be funkcióját, ha rugalmasan alkalmazkodik a munkaerő-piaci helyzethez, részmunkaidőt és egyéb rugalmas foglalkoztatási lehetőséget biztosít. A gondozók frissen tarthatják munkaerő-piaci készségeiket és vissza tudnak lépni a teljes foglalkoztatás világába, ha már nincsen szükség a gondozásra.

Fizetés: A gondozási támogatás a szociális biztonsági rendszeren keresztül lenne finanszírozható, és megfelelően kompenzálnia kell az informális gondozó jövedelem-kiesését. Úgy kell kialakítani, hogy inkább a gondozás és a munka, mint a munka teljes feladása legyen a gondozó számára elfogadható opció. Ez a támogatás azok számára is elérhető kell, hogy 
legyen, akik nem foglalkoztatottak a gondozás időszakában (munkahelykeresők). A gondozási függőség nem érintheti hátrányosan az emberek életét. A megfelelő gondozási támogatás érdekes lehetőség a nemi egyenlőtlenségek csökkentésére is a gondozás során.

A szociális jogok fenntartása: a gondozást végzőknek éppoly szociális jogaik kell, legyenek, mint a munka világában élőknek. Jogot kell biztosítani a munkanélküli juttatásokhoz, egészségbiztosításhoz, és természetesen a nyugdíj jogosultsághoz is. A jelenlegi felosztó, kirovó rendszerek - melyek magukban foglalják a nők (gender) egyenlőség biztosítását - és a privát nyugdíjrendszerek esetében is ugyanúgy kell az informális gondozók biztonságát szavatolni, mint a gondozást nem végzőkét.

Támogató szolgáltatások a gondozóknak: az informális gondozás egy munka, még akkor is, ha gyakran nem úgy értékelik. Ezért aztán az informális gondozókat támogatni kell, a házi, személyes és egészségügyi szolgáltatások széles körével, amelyet saját otthonában, vagy nappali központokban biztosítanak, valamint hozzáférhetőséget a képzésekhez, támogató kapcsolatokhoz a formális szociális gondoskodás, az egészségügyi ellátás, illetve a családgondozás segítségével, amely lehetővé teszi, hogy az informális gondozó helyettesítő szolgáltatásokat vehessen igénybe.

Összekapcsolódó, rendszerszerü gondozási struktúrák kialakítása: a gondozási támogatás jogi szabályozása csak az egyik lehetőség annak elérésére, hogy megfelelő tiszteletet és jólétet biztosítsanak az idősebb embereknek, gondozásuk és támogatásuk során. A komplex politikák magukba foglalják az általános hozzáférést a formális gondozás formáihoz, a prevenció és rehabilitáció lehetőségeihez, az integrált gondozáshoz, Eegészségügyi ellátásokhoz, kor-barát környezethez, minőség ellenőrzéshez, és a szolgáltatások monitorozásához, amelyek szintén csökkentik az informális gondozók terheit.

- $\quad$ A foglalkoztatók támogatása: a munkáltatók nem ismerhetik a munka és a gondozás összeegyeztetésének kihívásait. Információkkal kell ellátni őket, hogyan lehet megőrizni és fejleszteni a munkavállalók produktivitását, erősíteni a kölcsönös megértést a munkavállaló és a kollégái között. Segíteni kell abban is, hogyan tudnak a munkavállalók megállapodni, és hogyan lesznek pozitív értelemben érzékenyebbek a kollégáik helyzete iránt.

\section{Mik a támogató szolgáltatások?}

A megfelelő szolgáltatások hiányában a gondozók gyakran izolálódnak, valamint túlterhelődnek. A szolgáltatásoknak a gondozás legfontosabb készségeit kell erősíteni, olyan képzéseket kell biztosítani, amelyek segítenek megelözni a legáltalánosabban elkövetett hibákat a gondozás során, segít hasonló problémákkal élők csoportos tapasztalatához jutni, 
valamint nappali és átmeneti helyettesítő szolgáltatásokat biztosít, hogy a gondozók átmenetileg mentesüljenek a folyamatos terhelés alól, legyenek elkötelezettek a magasabb színvonalú gondozás iránt, és legyenek elérhetőek.

A szolgáltatások befektetéseket igényelnek a tagállamok részéről, amelyeket meg kell osztani nemzeti, regionális, és helyi önkormányzati szinteken. Ez a befektetés - amelyet az európai strukturális és befektetési alapok támogathatnak és irányíthatnak - nemzeti és helyi szinten valósulhat meg. Ezért aztán a hozzáférés és a minőségi infrastruktúra monitorozása az Európai Szemeszter feladata lehet. A befektetés ezekbe a gondozási szolgáltatásokba szociális befektetésként értelmezhetőek, így nagyon fontos, hogy biztosításuk hosszú távon kerüljön meghatározásra és vizsgálatra.

Az Eurofound 2015-ben vizsgálta a gondozási támogatási rendszereket a hosszú tartamú gondozás összefüggésében. Sok EU-tagállam már korábban is felismerte a családi gondozás jelentőségét. Nagy részük biztosít valamilyen rövid időtartamú támogatást, amely gyakran nem fizetett távollét a munka világától. Ezek a gondozási célú szabadságok arra az esetre szólnak, ha hirtelen történik valami a családtaggal. A munkavállaló védelme a legtöbb esetben szintén jár az ilyen esetekben. A munkaidő rugalmasabb kezelése szintén több országban gyakorlatként jelentkezik (18 országban). Néhány országban a hosszabb tartamú gondozási támogatás (egy év, vagy néhány év) szintén biztosított, amely segít hosszabb, intenzív gondozás biztosításában. Általában a munkavállaló visszafoglalkoztatása szintén garantált ezekben az országokban.

\section{Gyermekgondozás, a nagyszülők szerepe}

A munka és a gondozás másik aspektusa az unokák gondozása a nagyszülők által. A női foglalkoztatás emelkedésével a gyermekgondozásba való befektetés és a szülök gyermekgondozási támogatása is fontos feladat. A nagyapák 49\%-a és a nagymamák 58\%-a biztosít gondozást unokáiknak. A nagyszülői segítség csökkenti a gyermekgondozással járó szolgáltatások költségeit, és hozzájárul a munka és a családi élet összeegyeztetéséhez is. Nagyon sok nagyszülő ezek közül még munkavállalási (aktív) korban van.

A nagyszülők számára biztosítani kell a szülői gyermekgondozási díjat. Ha a gondozási díj átvihető a családon belül azok számára, akik a gondozást biztosítják, a nagyszülők segíteni tudják a gyermekek felnevelkedését, valamint össze tudják egyeztetni a munka világát és a gondozás feladatait.

A szakpolitikáknak segítenie szükséges a munka és a családi felelősségek összeegyeztetését, ennek egyik lehetősége, ha az idősebb munkavállalóknak támogatásokat biztosítanak 
csakúgy, ahogyan sok országban szervezett szolgáltatásokat biztosítanak a gyermekek ellátására, annak érdekében, hogy a szülők ne rekedjenek ki a munkaeröpiacról.

Fordította és az összefoglalót írta:

Patyán László

Főiskolai docens

Debreceni Egyetem Egészségügyi Kar

Gerontológia tanszék 